\title{
On longevity and monitoring technologies of bridges: a survey study by the Japanese Society of Steel Construction
}

\section{$\operatorname{AUTHOR}(\mathrm{S}):$}

Watanabe, Eiichi; Furuta, Hitoshi; Yamaguchi, Takashi; Kano, Masato

\section{CITATION:}

Watanabe, Eiichi ... [et al]. On longevity and monitoring technologies of bridges: a survey study by the Japanese Society of Steel Construction. Structure and Infrastructure Engineering 2013, 10(4): 471-491

\section{ISSUE DATE:}

2013-03-06

URL:

http://hdl.handle.net/2433/198286

\section{RIGHT:}

The Version of Record of this manuscript has been published and is available in Structure and Infrastructure Engineering: Maintenance, Management, Life-Cycle Design and Performance (2014)

http://www.tandfonline.com/10.1080/15732479.2013.769008.; This is not the published version. Please cite only the published version.; この論文は出版社版でありません。引用の際には出版社版をご確認ご利用ください。 


\title{
On Longevity and Monitoring Technologies of Bridges
} - A Survey Study by Japanese Society of Steel Construction -

\author{
E. Watanabe
}

Professor Emeritus of Kyoto University, Chairperson of Board of Directors of Regional Planning Institute in Osaka

H. Furuta

Professor of Informatics of Kansai University, Takatsuki, Osaka

T. Yamaguchi

Professor of Osaka City University, Osaka

M. Kano

JIP Techno-Science Co., Osaka, Japan

\begin{abstract}
JSSC, Japanese Society of Steel Construction, has organized a special task committee and conducted a study on the recent development of maintenance, renewal and retrofitting for buildings and bridges of Japan. This paper describes outline of the study by the working group of bridges and consists of two parts. The first part is concerned with the survey on the technologies for the longevity of bridges whereas the second part is specifically concerned with the structural health monitoring technologies reflecting recent developments. In view of the fact that important terminologies such as lifetime and service life have been used differently throughout the world, some fundamental terminologies are reviewed, discussed and redefined in this paper. Furthermore, recent developments on the structural health monitoring technology are reviewed and the results are summarized in a matrix form. Lastly, voices of some local governments, owners of expressways and railroads are taken into account in the form of questionnaire and replies to propose future structural health monitoring system for traffic infrastructures.
\end{abstract}

\section{INTRODUCTION}

In recent years, with some exceptions the number of children is significantly decreasing and young people tend to seek easy jobs which do not necessarily require working hard with perspirations in the developed countries in particular and in some developing countries. In this view point, the education of engineers and important traditional technologies that have been acquired through generations are going to be forlorn and these facts are becoming deplorable social problems.

In the world of construction industry, the era of the new construction seems to be ending in most of the developed countries and how to maintain and manage the existing facilities are considered to be one of the most important paradigms. On the other hand, as the socio-economic activities, the scale of the production, consumption and scrap have been significantly increasing and the exhaustion of resources and the destruction of environment are being rapidly accelerated throughout the world. It is needless to say that the construction environment should be drastically changed from the era of scrap to the ecological use of existing stock of infrastructure. Therefore, the structural longevity and elongation of the lifetime of infrastructure should be regarded as increasingly important subjects at the present time and in the future.

According to the white paper of the Government of Japan, the lives of typical infrastructure such as roads and bridges are thought to be 60 years and that of harbors and coasts is 50 years, respectively (MLIT 2002). Furthermore, according to Nikkei Newspaper, the annual cost of maintenance, management, replacement of public infrastructure and restoration from natural disasters of Japan would be doubled from that of 2004 to 2030, namely would become from 5 trillion JPY to 10 trillion JPY. According to the detail of the white paper of Japanese Government, the following facts on the infrastructure are worth mentioning. Assuming the total in- 
vestment remains as it is, the figures from those in the year of 2000 will increase or decrease respectively annually to those in the year of 2025 in Japan:

(1) The investment for the maintenance is predicted to increase, specifically, from 3.8 trillion JPY to 6.2 trillion JPY.

(2) The investment for the renewal is predicted to increase, specifically, from 0.3 trillion JPY to 3.7 trillion JPY.

(3) The investment for the newly-built is predicted to decrease, specifically, from 15.9 trillion JPY to 9 trillion JPY.

(4) The stock of the infrastructure will be vastly accumulated.

\section{LIFETIME OF BRIDGES}

\subsection{Definition of Lifetime}

It is quite confusing to know that the definition of the lifetime varies considerably from places to places. In this paper, the "lifetime" may be defined as the period of time since structures have started to be in service until they cease to be used for some reasons or the final stage when they are possibly in service any further (JSSC 1991).

\subsection{Definition of Expected Lifetime}

The expected lifetime may be defined as the period of time in which structures are expected to satisfy the demand performance, to possess the physical load-carrying capacity and to fulfill the serviceability.

\subsection{Function and Performance}

Performance refers to the structural capacity based on the field inspection data and the structural health assessment taking into account the deterioration of infrastructure. On the other hand, the function implies updated capacities meeting the current standard of the wheel loadings, natural forces such as wind and earthquake excitations, river flow, design traffic flow and so forth.

It is a general practice to decide the maintenance plan based on the field inspection data and the structural health assessment of bridges taking into account their deterioration rate. However, the old bridges built in the past were based on different old codes from now with respect to loads, earthquake-resistant design and river conditions and so forth, thus their function does not correspond to the present design codes. Thus, the judgment on the bridge replacement on the basis of the bridge health assessment alone may lead to wrong decisions. From this standpoint, the final decision requires the functionality in addition to the health assessment as explained in the following. In this paper, the countermeasure such as earthquake-resistance retrofitting is not considered for convenience. However, base-isolation will be regarded as a method to improve the performance in this paper.

\subsection{Classification and Concepts of Lifetime}

Lifetime may be classified into physical, functional and economic lifetimes (Kato 1983) as shown in Figure 1 and Table 1.

\section{(1) Physical lifetime}

It refers to the lifetime of an existing bridge which may have to be renewed by a new bridge upon significant reduction of the load-carrying capacity or by the troubles encountered during the service but deemed difficult to meet these demands by just reforming the present bridge. As shown in Figure 1 (a), it represents the period from the initial state of a bridge to the time when its performance decreases and coincides with the performance corresponding to the serviceability limit. It frequently happens to restore the performance by intermediate repair, retrofitting or replacement works. 
It refers to the lifetime of an existing bridge which may have to be renewed by a new bridge when the widening of roadway width or the up-grading of the traffic loads are legally demanded but deemed difficult to meet these demands by only reforming the present bridge. As shown in Figure 1 (b), it represents the period from the initial state of a bridge to the time when its demand performance is changed beyond the present performance.

\section{Economic lifetime}

It refers to the lifetime of an existing bridge which may have to be renewed by a new bridge when the up-grading the existing bridge is judged much more expensive than building a new bridge. In Figure 1 (c), it represents the period from the initial state of a bridge to the time when its cost for the repair and retrofitting become greater than that for the replacement.

Table 2 shows several examples of physical, functional and economic lifetimes.

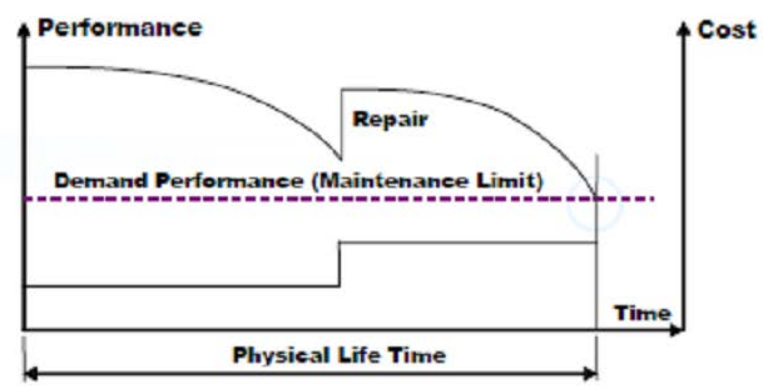

(a)

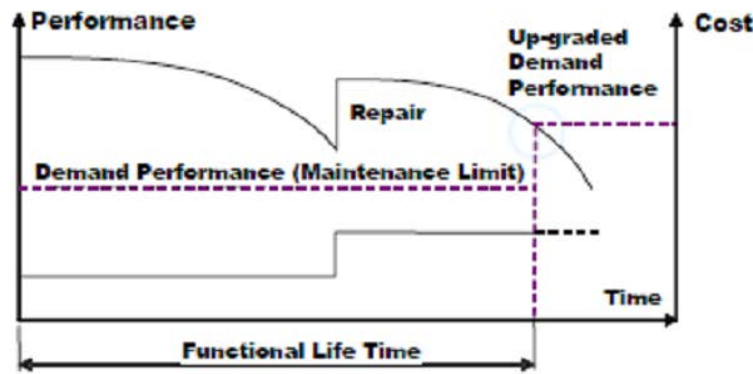

(b)

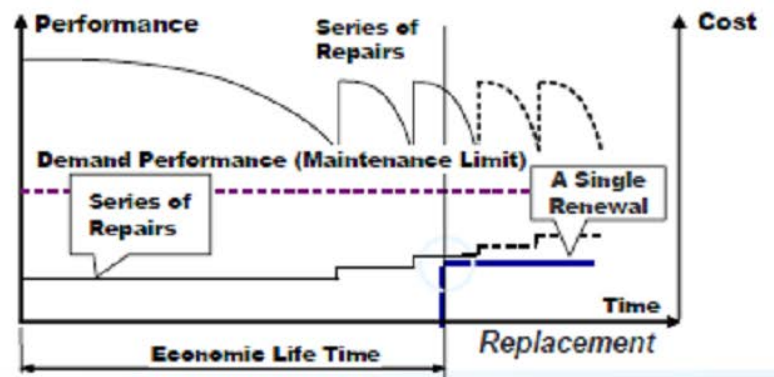

(c)

Figure 1. Chronological change of lifetime

\subsection{Chronological Change of Reasons for Replacement of Bridges}

Figure 2 shows the chronological change of reasons for bridge replacement in Japan (PWRI 1997, BMSG 2004). Figure 2 (a) describes the reasons for bridge replacement during the period of 1977-1986. These reasons may be listed in the order of larger percentage:

(1) Improvement of road alignment

(2) Improve the functional obsoleteness

(3) Structural defects such as corrosion

(4) Insufficient load-carrying capacity 
Table 1. Comparison of Lifetimes.

\begin{tabular}{|c|c|c|c|c|c|}
\hline \multirow[b]{2}{*}{$\begin{array}{l}\text { Classification } \\
\text { of Lifetime }\end{array}$} & \multirow[b]{2}{*}{ Characteristics } & \multirow[b]{2}{*}{$\begin{array}{l}\text { Judgment of } \\
\text { Lifetime }\end{array}$} & \multicolumn{2}{|c|}{ Application } & \multirow[b]{2}{*}{$\begin{array}{l}\text { Judgment of Econo- } \\
\text { my/Comparison of } \\
\text { Cost }\end{array}$} \\
\hline & & & $\begin{array}{l}\text { Whole } \\
\text { Bridge Sys- } \\
\text { tem }\end{array}$ & $\begin{array}{l}\text { Structural } \\
\text { Elements: } \\
\text { (Girders, } \\
\text { Slabs, etc) }\end{array}$ & \\
\hline $\begin{array}{l}\text { Physical } \\
\text { Lifetime }\end{array}$ & $\begin{array}{l}\text { Limit of Use- } \\
\text { fulness }\end{array}$ & $\begin{array}{l}\text { Inspection, } \\
\text { Structural } \\
\text { Health As- } \\
\text { sessment }\end{array}$ & No & Yes & No \\
\hline $\begin{array}{l}\text { Functional } \\
\text { Lifetime }\end{array}$ & $\begin{array}{l}\text { Difficult to de- } \\
\text { fine the index } \\
\text { appropriately } \\
\text { and point out } \\
\text { when }\end{array}$ & $\begin{array}{l}\text { When budget } \\
\text { is insufficient, } \\
\text { the lifetime } \\
\text { will become } \\
\text { longer }\end{array}$ & Yes & No & No \\
\hline $\begin{array}{l}\text { Economic } \\
\text { Lifetime }\end{array}$ & $\begin{array}{l}\text { Replacement is } \\
\text { deemed cheap- } \\
\text { er }\end{array}$ & $\begin{array}{l}\text { Comparison } \\
\text { of cost and } \\
\text { decision- } \\
\text { making }\end{array}$ & Yes & Yes & Yes \\
\hline
\end{tabular}

Table 2. Examples of physical, functional and economic lifetimes.

\begin{tabular}{lll}
\hline & Whole Bridge System & $\begin{array}{l}\text { Structural Components (main } \\
\text { girders, deck plate, etc) }\end{array}$ \\
\hline Physical Lifetime & $\begin{array}{l}\text { Traffic suspension, left or or } \\
\text { scrapped due to insufficiency to } \\
\text { carry external load. Lifetime is } \\
\text { the same as that of components repair is judged to } \\
\text { insufficient to meet the bearing } \\
\text { capacity and only the replace- } \\
\text { ment is the solution }\end{array}$ \\
& $\begin{array}{l}\text { Narrow road width, road align- } \\
\text { ment is not good, refitting river } \\
\text { flow is planned or aesthetically } \\
\text { poor }\end{array}$ & $\begin{array}{l}\text { Road width, road alignment } \\
\text { depend on that of the whole } \\
\text { bridge system. Partial aesthetic } \\
\text { retrofitting may be possible }\end{array}$ \\
\hline Functional Lifetime & $\begin{array}{l}\text { Replacement is judged better } \\
\text { than continual repairs }\end{array}$ & $\begin{array}{l}\text { Replacement is judged better } \\
\text { than continual repairs }\end{array}$ \\
\hline Economic Lifetime & & \\
\hline
\end{tabular}

After 10 years, some of the reasons for replacement of bridges have changed as shown in Figure 2. For example, the replacement due to damage corresponds to only $1 / 5$ of the total replacements. Most of the replacements are due to the improvement of road alignment, refit of river flow and widening of road width. The percentage of the improvement of the functionality changed from $57 \%$ to $76 \%$.

\subsection{Definition of Technology toward Longevity}

The longevity technology refers to the technology and all methods of management including those for inspection, system, timing, judgment, measure and budget to prolong the lifetime beyond the expected lifetime.

The keywords for the longevity may be summarized as:

(1) Increase of bridge stocks

(2) In view of the limitation for budgetary appropriation, the scenario of "renewal of every bridge does not exist any more.

(3) The national and local governmental principle for the preventive management is supported by the authorized experts.

(4) The concept of longevity for those newly-built and already existing are different.

(5) The performance-based specification is encouraged for the longevity by adopting innovative and development technologies. 


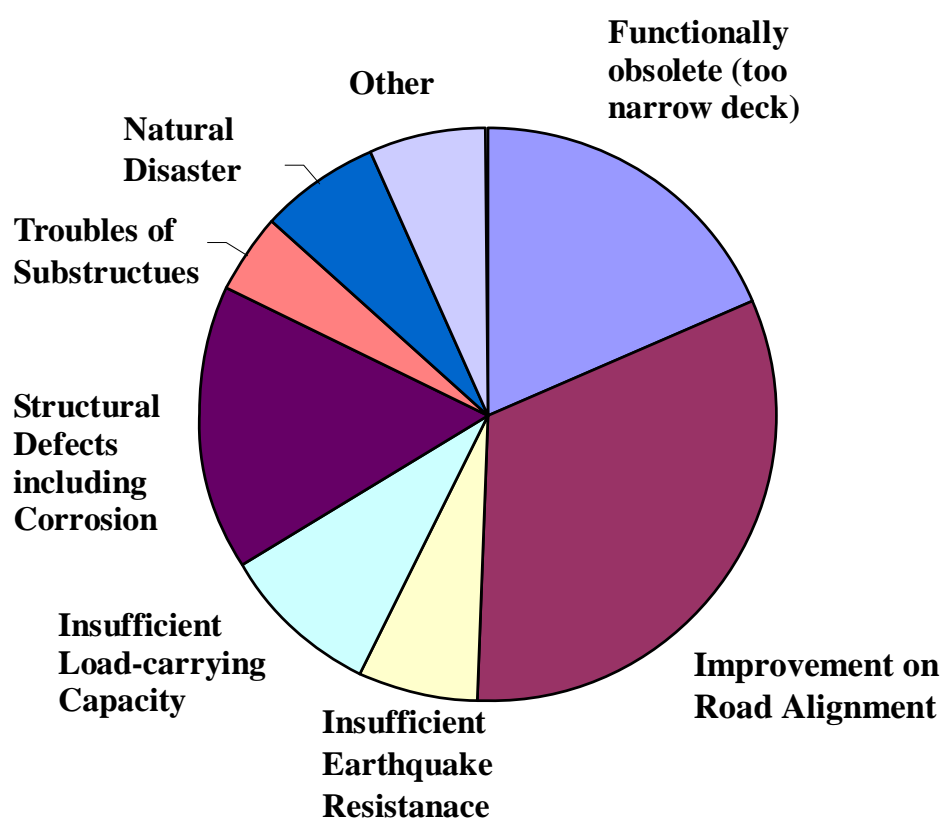

(a) Reasons of Replacing Road Bridges (1977-1986) (PWRI 1997)

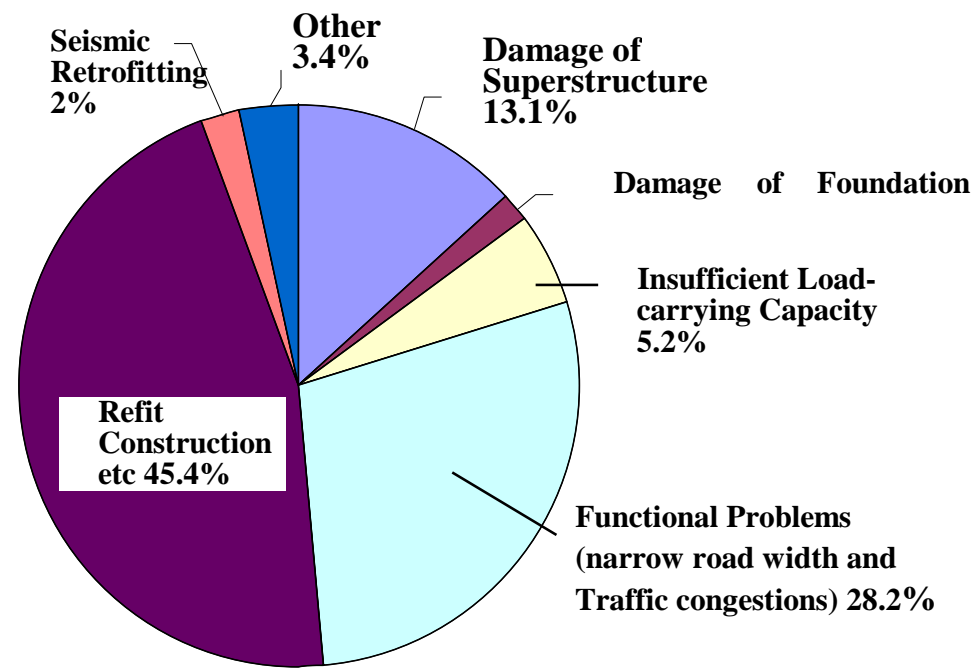

(b) Reasons of Replacing Road Bridges (1996) (BMSG 2004)

Figure 2. Chronological change of lifetime of Japanese roadway bridges

Figure 3 shows the ratio of the bridges with the lifetime over the age of 50 to those under 50 (MLIT 2008). It may be apparent that after the year of 2030, the ratio of bridges over the age of 50 becomes more significant. 


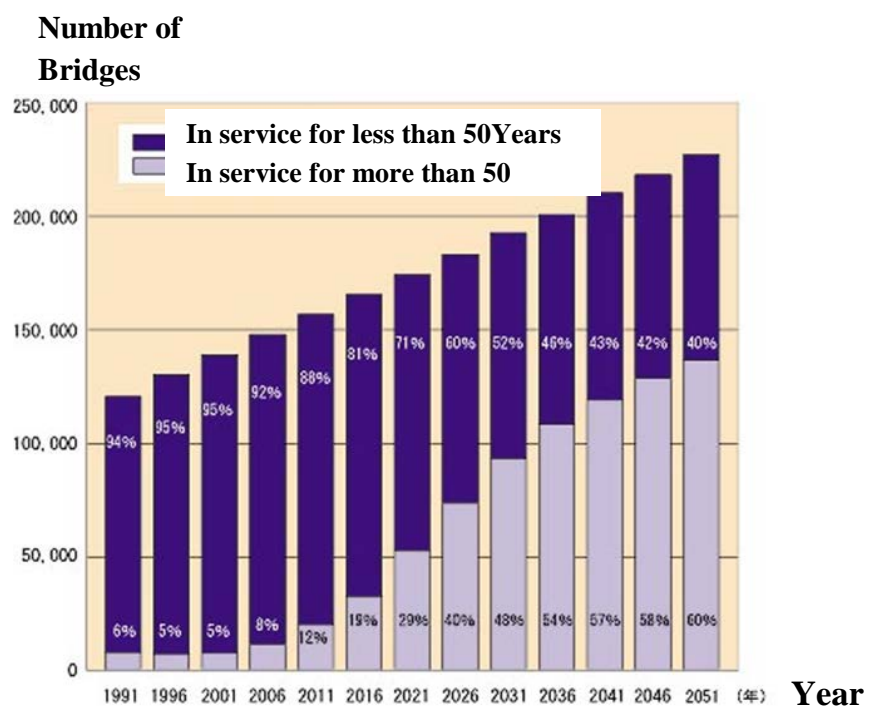

Figure 3. Chronological change of ratio of the bridges with the age over 50 to those under 50.

\subsection{Target Lifetime}

The target lifetime is not defined by the structures but by the manager.

(1) It is the matter of consciousness of the managers and the public opinion.

(2) The limit performance for management varies depending on the demand performance of the time.

(3) Theoretically, steel structures are considered to be ever-lasting structures.

(4) The target lifetime may be considered to be 1.5 time of the lifetime of existing structures as shown in Figure 4 (Abe 2008).

(5) Even at the end of the target lifetime, the structures may not have to be renewed if they posses the sufficient structural health.

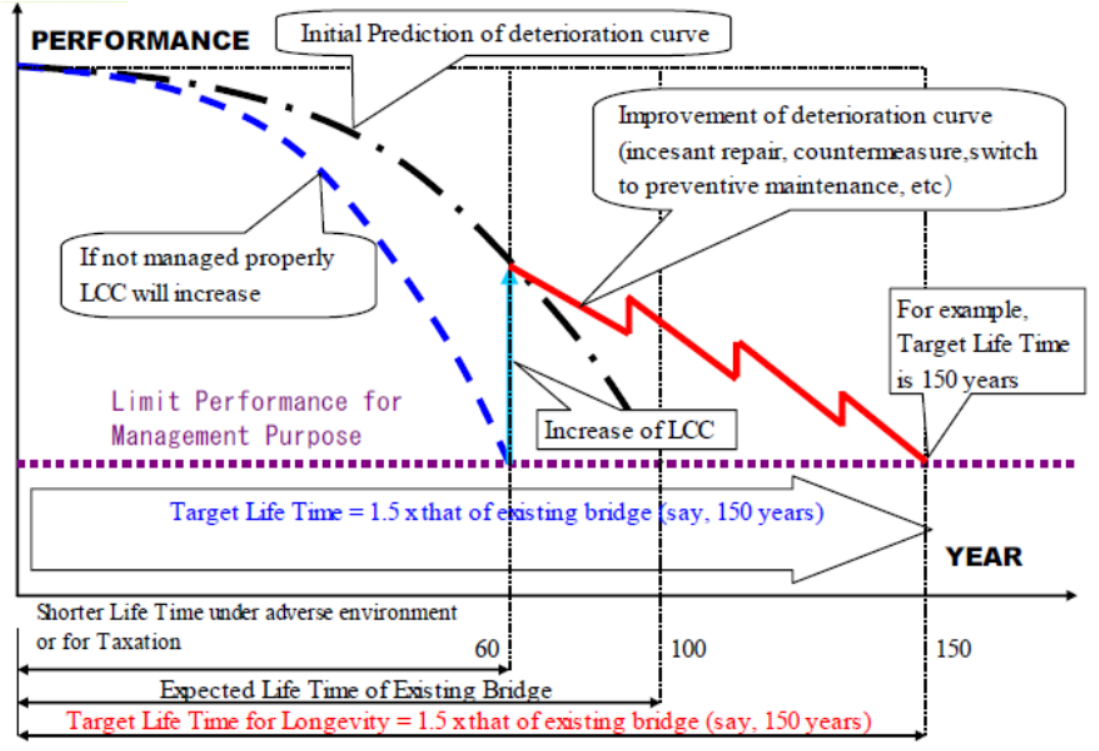

Figure 4. Performance and lifetime of bridges (Abe 2008).

\subsection{Management for Longevity}

The lifetime can be made longer or shorter than the initially expected one depending on the management method. 


\subsection{Setting of Basic Parameters for Determination of Lifetime for Steel Bridges}

The National Institute for Land and Infrastructure Management, NILIM, showed the statistics of the number of replaced bridge plotted against the year of replacement.

The statistical distribution is assumed to follow the Normal distribution and the parameters are so determined as to minimize the errors between the achieved record and the prediction. Table 3 shows the average lifetime and standard deviation of bridges built from 1920 to 2000 (NILIM 2004).

For those bridges built during the period of so-called "rapid economic progress" from the year 1961 to 1980 the statistics show that the average lifetime is 70 years with the standard deviation of 20 years. Thus, if the normal distribution is assumed and 95\% fractile of nonexceedance is assumed, this fractile corresponds to $1.65 \sigma$, the longevity of prolonged lifetime of 35 more years can be expected $(20 \times 1.65=35)$ as shown in Figure 5 . While those bridges built in recent years from 1981 to 2000, the average lifetime is 100 years with the standard deviation of 30 years. By the similar token, the longevity of 50 more years may be expected $(30 \times 1.65=50)$.

If different fractile other than 95\% is assumed, the expected average lifetime for steel bridges may be as listed in Table 4. Thus, for recent bridges built after 1980, the expected lifetime may be regarded to be 150 years.

Table 3. Chronological characteristics of replacement of steel bridges (NILIM 2004).

\begin{tabular}{lccl}
\hline $\begin{array}{l}\text { Completed } \\
\text { Year }\end{array}$ & $\begin{array}{l}\text { Average Life- } \\
\text { time in Years }\end{array}$ & $\begin{array}{l}\text { Standard Devia- } \\
\text { tion in Years }\end{array}$ & Remarks \\
\hline $1920-1930$ & 50 & 10 & \\
\hline $1931-1940$ & 40 & 10 & \\
\hline $1941-1950$ & 30 & 10 & $2^{\text {nd }}$ World War \\
\hline $1951-1960$ & 60 & 20 & \\
\hline $1961-1970$ & 70 & 20 & \\
\hline $1971-1980$ & 70 & 20 & \\
\hline $1981-1990$ & 100 & 30 & Scarce data \\
\hline $1991-2000$ & 100 & 30 & Scarce data \\
\hline
\end{tabular}

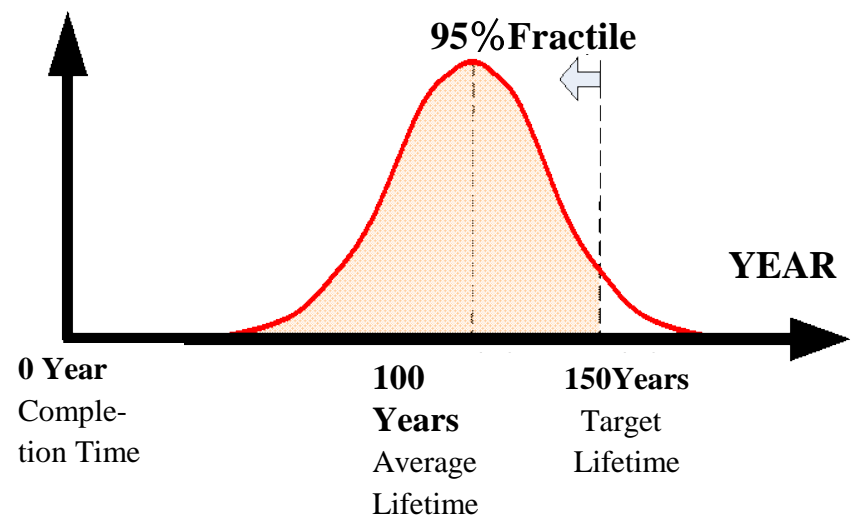

LIFETIME

Figure 5. Target lifetime for bridges.

Table 4. Expected average lifetime of bridges for different probabilities of non-exceedance.

\begin{tabular}{|c|c|c|c|c|}
\hline \multirow[t]{2}{*}{ Era } & \multirow{2}{*}{$\begin{array}{l}\text { Average Life } \\
\text { Time }\end{array}$} & \multicolumn{3}{|c|}{$\begin{array}{l}\text { Expected average lifetime of bridges } \\
\text { for Probabilities of non-exceedance }\end{array}$} \\
\hline & & $90 \%$ & $95 \%$ & $99 \%$ \\
\hline
\end{tabular}




\begin{tabular}{ccccc}
\hline From 1960’s to 1970’s & 70 & 96 Yeas & 103 Years & 117 Years \\
\hline From 1980's & 100 & 139 Years & 150 Years & 170 Years \\
\hline
\end{tabular}

\section{PRESENT STATUS OF TECHNOLOGIES FOR LONGEVITY OF BRIDGES}

\subsection{Change of Social Demand}

The philosophy of essential maintenance, namely, "rebuilding bridges when they become older than the lifetime" in the past is nowadays shifting to the philosophy of preventive maintenance and building durable bridges to prolong their service life.

\subsection{Type of Damages for Steel Bridges}

Most damages are caused by the defective structural characteristics and environmental effects. The most popular damages of steel bridges are considered to be fatigue and corrosion.

\subsection{System for Longevity Technology}

Figure 6.shows the vision of longevity technology and expected developments of technologies for each step of construction projects.

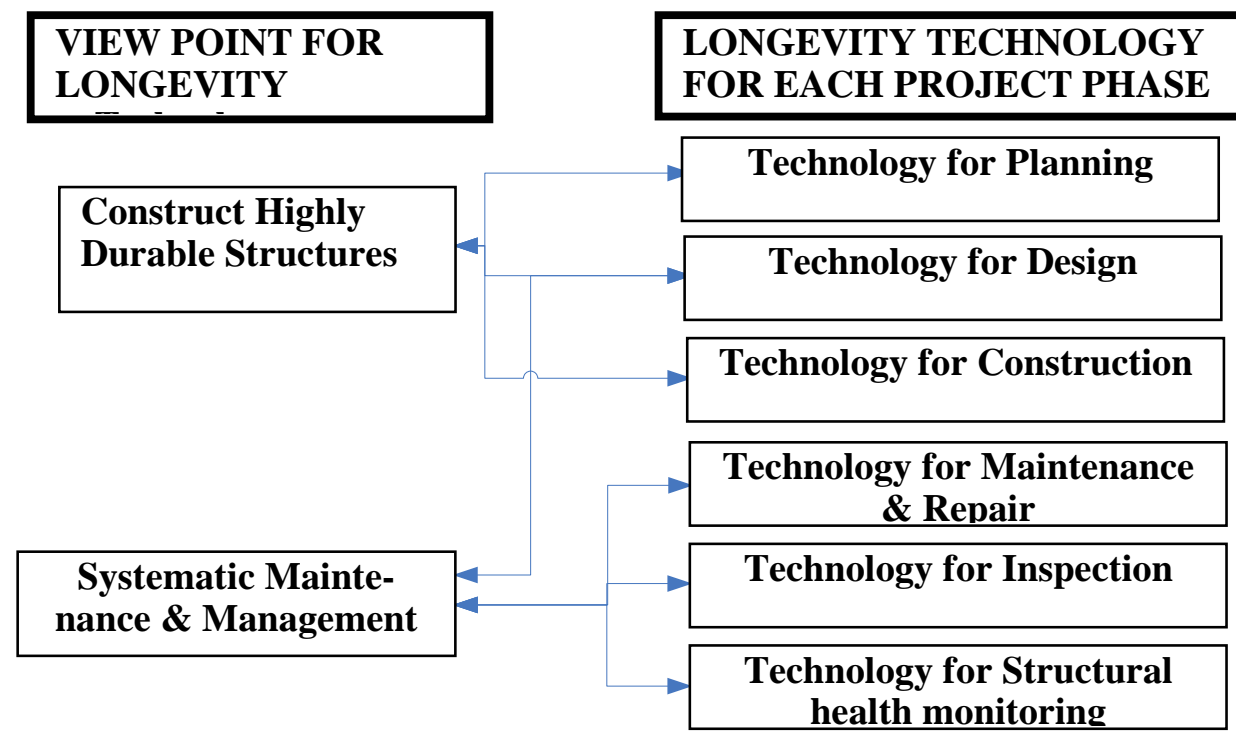

Figure 6. Vision of longevity technology and expected developments of technologies for each step of construction projects.

\subsection{Cause of Damages for Bridge Parts and Structural Members}

Figure 7 shows the causes of damage of bridge parts and elements of steel bridges. Described qare the locations of damaged steel parts or members, causes of damage and the type of damages. It will be seen that the fatigue and corrosion are the most popular damages for steel bridges. 


\subsection{Anti-fatigue Technologies}

For road bridges, the fatigue design has been introduced in Japan only quite recently. The countermeasure consist of reduction of stress concentration, reduction of residual stresses. Not only in the maintenance but also they should be taken into account at the planning and design steps. Recently, the following two countermeasures are to be noted.

anti-fatigue steel The steel itself has a desirable characteristics of fatigue-resistance through the adjustment of chemical ingredients and metal texture.

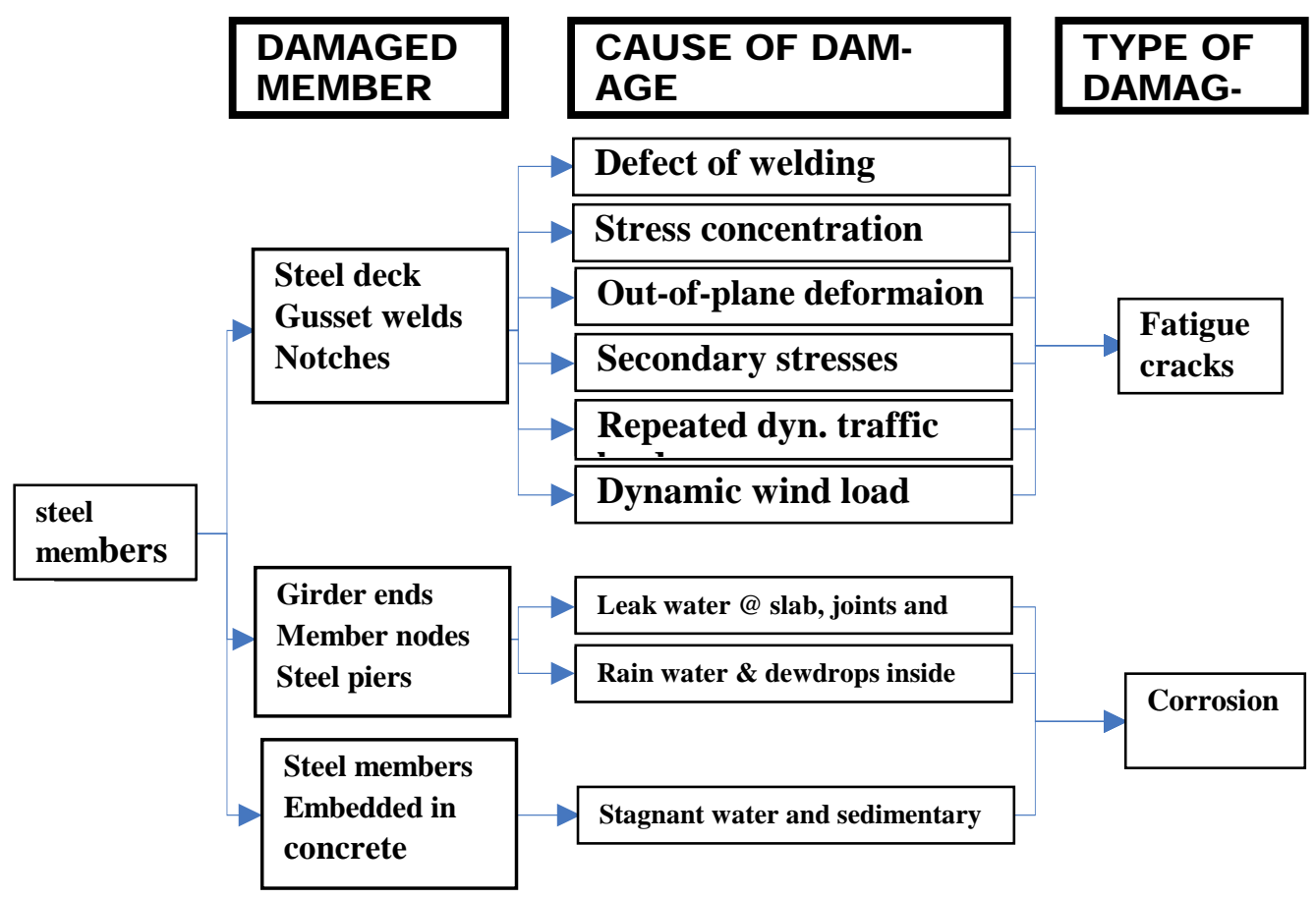

Figure 7. Causes of damage of bridge parts and elements.

(2) UTI, Ultrasonic Impact Treatment Impact of ultrasonic wave is applied to the weld in order to have the following effects:

(a) Tensile residual stresses can be converted to compressive.

(b) Reduce the stress concentration by smoothing out the surface of weld.

(c) Increase the surface toughness.

\subsection{Anti-corrosion Technologies}

As has been described above, the corrosion is regarded as one of the most serious problems for steel structures. Not only to those in the area near the sea zone susceptible to salt water but to those cold area where anti-freeze is used inevitably, bridges tend to be corroded much faster than in the other locations. Furthermore, attention must be paid to some specific locations of bridge parts of elements where water tends to be stagnant and pooled or the humidity is easily kept high. Sometimes dewdrops become also harmful unless they dry out. Figure 8 shows an example of dehumidifier used to keep inside a girder dry (Kaneko 1999). Figure 9 also shows an example of dehumidifier used for main cables of a suspension bridge (Kitagawa 2001). 
(a) This is to dry up inside girder by removing humidity to prevent dewdrops using either dehumidifiers or ventilators.

(b) Clean-up technologies: This is to remove the dirt and salt from the surface

(2) Cathodic protection methods

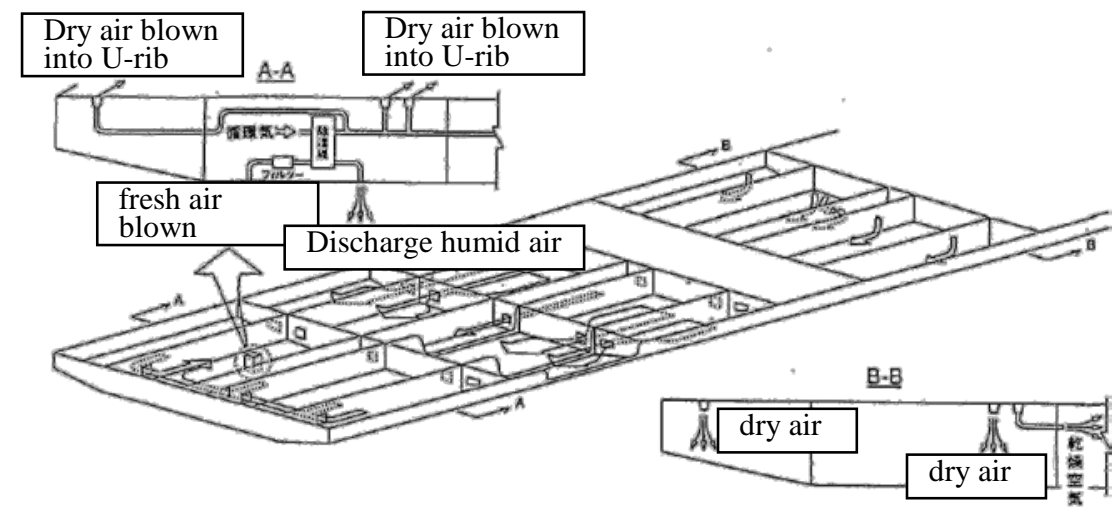

Figure 8. Dry air dehumidifier inside a bridge deck.

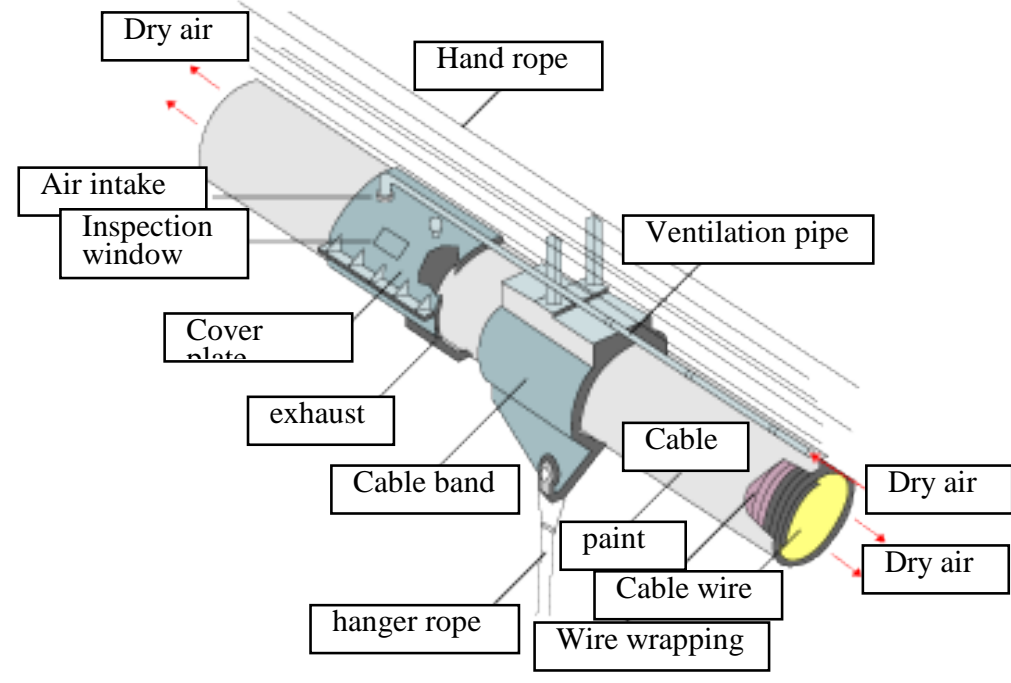

Figure 9. Dry air infusion system for cables.

Because of the severe corrosive environment, corrosion protection should be made, especially for the parts just below the M.L.W.L. when severe local corrosion occurs. For such parts, cathodic protection is generally applied.

(a) Cathodic protection without external electric power

(b) Cathodic protection with external electric power

(c) Cathodic protection in the air

(3) Other anti-corrosion methods

The other coating methods include (a) painting, (b) organic lining, (c) petrolatum lining and (d) inorganic lining. The inorganic linings include metal linings such as titanium-clad lining (JTS 2000, Nippon Steel 2000), stainless steel lining, thermal spraying using zinc, aluminum and aluminum al- 
loys (JAPH 1999). Figure 10 shows an example of cathodic protection without external power source (Ishida 2006).

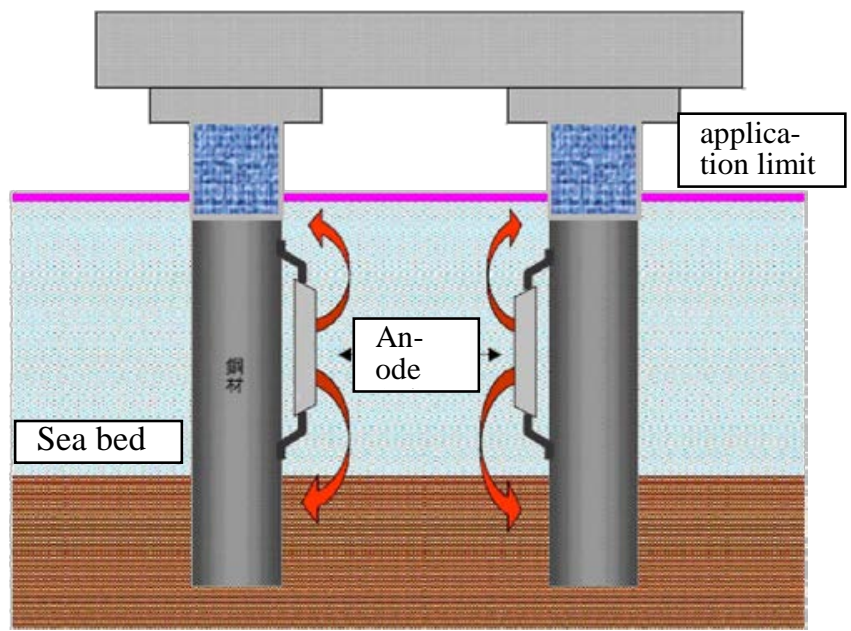

Figure 10. Cathodic protection (without external source power).

\subsection{Other Technologies}

(1) Technologies for planning and design stages

The assessment is required taking into account LCC considering the construction site and selection of structural type.

(2) Inspection technology

(a) Anti-fatigue inspection: In the past, the crack inspection was first done by flesh eyes. After confirmation of problems such as peeling-off of painting some detection tests were carried out. However, this method has many shortcomings such as cost, labor, and impossible when eye observation is impossible. $\rightarrow$ A wireless detection technology may be applied by placing IC tags at the place where cracks are expected to initiate.

(b) Anti-corrosion inspection: It may be very useful to find out corrosion at the place where eye observation is impossible such as reinforcements in concrete.

\section{EXPECTED TECHNOLOGIES FOR LONGEVITY}

\subsection{Current Attitude of Road Owners}

Depending on the demand performance, road owners are interested in the following structural maintenance matters:

1) Essential maintenance to repair a great damage.

2) Preventive maintenance to repair a light damage

3) Up-grading of wheel loads and earthquake retrofitting

4) Daily maintenance such as cleaning up road surface, drainage pipes. 


\subsection{Expected Longevity Technology}

Three companies sent their comments: Companies A, B, C and D regarding the present situation and the future issues..

Table 5. Company A

\begin{tabular}{lll}
\hline & \multicolumn{1}{c}{ Present situation } & \multicolumn{1}{c}{ Future issues } \\
\hline Purpose & $\begin{array}{l}\text { Lack of engineers/increasing mainte- } \\
\text { nance cost }\end{array}$ & $\begin{array}{l}\text { Education of specialist/ outsourcing/ } \\
\text { disclosure of information/ accountability }\end{array}$ \\
\hline Inspection & $\begin{array}{l}\text { Close inspection once every 5 years/ re- } \\
\text { peated damage increasing/ Gap between } \\
\text { Inspection \& repair }\end{array}$ & $\begin{array}{l}\text { Priority in inspection/ remote controlled } \\
\text { inspection/ simultaneous check of re- } \\
\text { peated damage and inspection desirable. }\end{array}$ \\
\hline Structural health & $\begin{array}{l}\text { Bridge part or whole bridge system? Not } \\
\text { well established. Riding comfort more } \\
\text { emphasized. }\end{array}$ & $\begin{array}{l}\text { Assessment considering cause of deteri- } \\
\text { oration and structural importance/ de- } \\
\text { mand performance of structures }\end{array}$ \\
\hline Maintenance plan & $\begin{array}{l}\text { Gap between management level \& actual } \\
\text { damage level. Prediction of deterioration } \\
\text { still not established yet. }\end{array}$ & $\begin{array}{l}\text { Development of reliable investigation } \\
\text { and assessment methods/ optimum com- } \\
\text { bination of essential and preventive } \\
\text { maintenances }\end{array}$ \\
\hline $\begin{array}{l}\text { Information man- } \\
\text { agement }\end{array}$ & $\begin{array}{l}\text { Gap between prediction and reality. Vol- } \\
\text { ume of data too much. }\end{array}$ & $\begin{array}{l}\text { Promotion of data synthesis and its shar- } \\
\text { ing together/ realization of prompt input } \\
\text { data at the site and construction of data- } \\
\text { base }\end{array}$ \\
\hline
\end{tabular}

Table 6. Company B

\begin{tabular}{lll}
\hline & \multicolumn{1}{c}{ Present situation } & \multicolumn{1}{c}{ Future issues } \\
\hline Purpose & $\begin{array}{l}\text { Significant increase of damages/ con- } \\
\text { struction of logic model/ CS (Customer } \\
\text { Satisfaction) survey \& verification }\end{array}$ & $\begin{array}{l}\text { Maintenance of appropriate management } \\
\text { level/ Establish management cycle and } \\
\text { accountability }\end{array}$ \\
\hline Inspection & $\begin{array}{l}\text { Daily \& scheduled inspection (frequency } \\
\text { depends on routes)/ Check done every } \\
\text { year based on logic model }\end{array}$ & $\begin{array}{l}\text { Priority in inspection/ remote controlled } \\
\text { inspection/ development of structural } \\
\text { health monitoring technology/ re- } \\
\text { evaluation of repair/ light repair work } \\
\text { during inspection }\end{array}$ \\
\hline Structural health & $\begin{array}{l}\text { Structural health assessment for each part } \\
\text { or component/ instance of damage input } \\
\text { into DB }\end{array}$ & $\begin{array}{l}\text { Assessment of structural health of a } \\
\text { whole bridge system/ Demand perfor- } \\
\text { mance of structure }\end{array}$ \\
\hline Maintenance plan & $\begin{array}{l}\text { Management outcome index is set/ Re- } \\
\text { pair plan is made based on present dam- } \\
\text { age map }\end{array}$ & $\begin{array}{l}\text { Speedy detection of deteriorations by } \\
\text { grouping/ development of technology to } \\
\text { find the minimum LCC }\end{array}$ \\
\hline $\begin{array}{l}\text { Information man- } \\
\text { agement }\end{array}$ & $\begin{array}{l}\text { Database and AMS already constructed } \\
\text { and they are used as maintenance infor- } \\
\text { mation / It is being applied to support } \\
\text { short-term repair plan }\end{array}$ & $\begin{array}{l}\text { History record of repair used for the next } \\
\text { inspection/ It is now used as a support- } \\
\text { ing tool for long-term maintenance plan }\end{array}$ \\
\hline
\end{tabular}

Table 7. Company C

\begin{tabular}{lll}
\hline & \multicolumn{1}{c}{ Present situation } & \multicolumn{1}{c}{ Future issues } \\
\hline Purpose & $\begin{array}{l}\text { Purpose of maintenance is for the long- } \\
\text { term structural health/ Preventive } \\
\text { maintenance is for determination of ap- } \\
\text { propriate management level. }\end{array}$ & $\begin{array}{l}\text { 200-year lifetime is expected/ heritage } \\
\text { of technology and its sophistication }\end{array}$ \\
\hline Inspection & $\begin{array}{l}\text { Patrol, basics, precise inspection for } \\
\text { long-span bridges/ Need for check of } \\
\text { paint thickness for the re-painting plan }\end{array}$ & $\begin{array}{l}\text { Grade-up of remote sensing and struc- } \\
\text { tural health monitoring/ continue to ob- } \\
\text { tain information on fatigue study for } \\
\text { steel bridges }\end{array}$ \\
\hline Structural health & $\begin{array}{l}\text { Structural health assessment for each part } \\
\text { or component/ instance of damage input } \\
\text { into DB }\end{array}$ & $\begin{array}{l}\text { Assessment of structural health of a } \\
\text { whole bridge system/ Demand perfor- } \\
\text { mance of structure }\end{array}$ \\
\hline Maintenance plan & Annual diagnosis and assessment of & Road users'needs reflected to demand \\
\hline
\end{tabular}




\begin{tabular}{lll}
\hline & $\begin{array}{l}\text { structural health on structural compo- } \\
\text { nents/ quantitative structural health con- } \\
\text { ducted }\end{array}$ & $\begin{array}{l}\text { performance/ determination of manage- } \\
\text { ment level for each facility (priority }\end{array}$ \\
\hline $\begin{array}{l}\text { Information man- } \\
\text { agement }\end{array}$ & $\begin{array}{l}\text { Database reflecting inspection results/ es- } \\
\text { tablish management method for strait- } \\
\text { crossing long-span bridges }\end{array}$ & $\begin{array}{l}\text { Effective use of DB/ development of } \\
\text { management system for land-based road } \\
\text { bridges }\end{array}$ \\
\hline
\end{tabular}

Table 8. Company D

\begin{tabular}{lll}
\hline & \multicolumn{1}{c}{ Present situation } & \multicolumn{1}{c}{ Future issues } \\
\hline Purpose & $\begin{array}{l}\text { Preservation of safety, serviceability \& } \\
\text { restorability/ unfortunately, currently on- } \\
\text { ly essential maintenance }\end{array}$ & $\begin{array}{l}\text { Education of technology to young engi- } \\
\text { neers/ accountability }\end{array}$ \\
\hline Inspection & $\begin{array}{l}\text { Regular inspection: once in every two } \\
\text { years/ detailed inspection: once in every } \\
10 \text { to 15 years/frequency of inspection } \\
\text { differs on type of structures }\end{array}$ & $\begin{array}{l}\text { Education of structural health examina- } \\
\text { tion tests to engineers/ structural health } \\
\text { important view point and prediction } \\
\text { technology of deterioration }\end{array}$ \\
\hline Structural health & $\begin{array}{l}\text { Assessment on facilities is done depend- } \\
\text { ing on management rule/ assessment is } \\
\text { based on present degree of deterioration } \\
\text { + future deterioration }\end{array}$ & $\begin{array}{l}\text { Objective index is desirably used for } \\
\text { judgment of priority/ good balance be- } \\
\text { tween the demand performance and the } \\
\text { economy }\end{array}$ \\
\hline Maintenance plan & $\begin{array}{l}\text { Correlation between management level } \\
\text { and cost unknown/ maintenance man- }\end{array}$ & $\begin{array}{l}\text { Feedback is necessary after projects are } \\
\text { completed/ establishment of PDCA cy- } \\
\text { agement plan for about 5 years term is } \\
\text { cles These will make it possible to estab- } \\
\text { lish preventive management }\end{array}$ \\
\hline $\begin{array}{l}\text { Information man- } \\
\text { agement }\end{array}$ & $\begin{array}{l}\text { Database of inspection data and mainte- } \\
\text { nance management information has been } \\
\text { constructed/ But BMS has not been in- } \\
\text { troduced yet }\end{array}$ & $\begin{array}{l}\text { Effective use of DB and its appropriate } \\
\text { renewal necessary to construct BMS }\end{array}$ \\
\hline & & \\
\hline
\end{tabular}

\subsection{Several problems to be solved}

There are many problems remain yet to be solved. These may be summarized below:

(1) Difference of management level (demand performance):

Not only the natural environment but also socio-economic environment are to be considered for the determination of lifetime and maintenance management.

(2) Limitation of budget (evaluation of LCC):

Balancing of cost for maintenance management by essential management and that by preventive maintenance must be established.

(3) Effective use of data (data sharing):

This is effective when combined with management system and good for accountability.

(4) Succession of technology:

The education of young engineers and out sourcing are important.

(5) Effective inspection method (frequency and methodology):

Priority in inspection, remote inspection and structural health monitoring technology are expected to be established. 


\section{NEEDS FOR STRUCTURAL HEALTH MONITORING AND REQUIRED PERFORMANCE}

\subsection{Background for Survey by Sending out Questionnaires to Owners of Structures}

Attempts were made to communicate with several owners of bridges to find the needs of structural health monitoring by sending questionnaires to them.

(1) Purpose for Surveying

Questionnaires are decided to be sent to know:

a. What is the needs for structural health monitoring and demand performance?

b. What is the latest sensors?

c. What is the latest assessment technology?

d. What is the applicability of structural health monitoring?

(2) Content of questionnaires and targets

Companies and organizations expected to respond to questionnaire are as follows:

a. Local governments (4)

b. Road owners (2 companies)

c. Railroad companies (4 companies)

d. Electric power and gas companies (2 companies)

Q1: Questionnaire 1

Question 1 Are there any problems in daily and periodical inspections on the stand point of longevity of bridges or steel structures?

Question 2 Can these problems be solved by structural health monitoring?

Question 3 What kind of structural health monitoring is expected?

Q2: Questionnaire 2

Question 1 What is expected to be detected, for example, cracks and corrosion?

Question 2 What are the objects for measurement?

Question 3 What kind of sensors are used?

\section{SURVEY OF STRUCTURAL HEALTH MONITORING TECHNOLOGIES AT THE PRESENT TIME}

\subsection{Summary of Investigation}

An extensive literature survey were conducted to know the technologies available at the present time and future applications.

\subsubsection{Purpose and Method of Investigation}

The purpose of investigation is as follows:

(1) to understand the present state of development of structural health monitoring technology

(2) to construct DB for references on structural health monitoring

(3) to extract possibilities and problems of application of structural health monitoring toward longevity of steel structures

The methodology of investigation is as follows:

(1) to collect the information of related books, reports including committee reports, and seminars that are published in Japan 
(2) to collect references on typical international conferences on the structural health monitoring

(3) to understand the present trend of technologies for structural health monitoring and evaluation of performance

(4) to classify the existing technologies by summarizing the target of application and methodology in the form of matrix

(5) to summarize the prospect of application of structural health monitoring technologies after reviewing references

\subsubsection{Target references of investigation}

The references reviewed are shown in Table 9

Table 9. List of references surveyed

\begin{tabular}{|c|c|c|c|c|}
\hline & classification & name & authors/publication & year \\
\hline \multirow[t]{13}{*}{ domestic } & \multirow[t]{2}{*}{ books } & Health structural health monitoring & S.Yamamoto et al & 1999 \\
\hline & & $\begin{array}{l}\text { Maintenance engineering of infra- } \\
\text { structure }\end{array}$ & $\begin{array}{l}\text { JSCE committee on } \\
\text { maintenance engi- } \\
\text { neering }\end{array}$ & 2004 \\
\hline & \multirow[t]{9}{*}{$\begin{array}{l}\text { Symposium } \\
\text { and seminars }\end{array}$} & $\begin{array}{l}\text { Report "basic study on advanced } \\
\text { structural health monitoring on } \\
\text { ships" }\end{array}$ & $\begin{array}{l}\text { JSNA (Japan Ship } \\
\text { Technology Research } \\
\text { Association) }\end{array}$ & 1998 \\
\hline & & $\begin{array}{l}\text { Present status and prospect for } \\
\text { maintenance of railroads }\end{array}$ & $\begin{array}{lr}\text { Railway } & \text { Technical } \\
\text { Research } & \text { Institute } \\
\text { seminar } & \end{array}$ & 2007 \\
\hline & & $\begin{array}{l}\text { Workshop on health diagnosis for } \\
\text { buildings }\end{array}$ & $\begin{array}{l}\text { Committee of struc- } \\
\text { tures, AIJ (Architec- } \\
\text { tural Institute of Ja- } \\
\text { pan) }\end{array}$ & 2005 \\
\hline & & $\begin{array}{l}\text { Prospect of structural health moni- } \\
\text { toring of performance implemented } \\
\text { by ubiquitous technology }\end{array}$ & $\begin{array}{l}\text { Committee of Infor- } \\
\text { mation system, AIJ }\end{array}$ & 2007 \\
\hline & & $\begin{array}{llll}\text { Journal of steel structures and } \\
\text { bridges, JSCE }\end{array}$ & $\begin{array}{l}\text { Committee of steel } \\
\text { structures, JSCE }\end{array}$ & 2008 \\
\hline & & $\begin{array}{l}\text { Seminar on "New inspection and } \\
\text { structural health monitoring tech- } \\
\text { nologies for steel structures" }\end{array}$ & $\begin{array}{l}\text { Committee of steel } \\
\text { structures, JSCE }\end{array}$ & 2007 \\
\hline & & $\begin{array}{l}\text { Guideline for structural health mon- } \\
\text { itoring of bridge vibrations }\end{array}$ & $\begin{array}{l}\text { Committee of struc- } \\
\text { tural engineering, } \\
\text { JSCE }\end{array}$ & 2000 \\
\hline & & $\begin{array}{l}\text { Structural health monitoring tech- } \\
\text { nologies for concrete structures }\end{array}$ & $\begin{array}{l}\text { Committee of con- } \\
\text { crete, JSCE }\end{array}$ & 2007 \\
\hline & & $\begin{array}{l}\text { Assessment of residual perfor- } \\
\text { mance and recovery technologies } \\
\text { for corroded steel structures }\end{array}$ & $\begin{array}{l}\text { Committee of steel } \\
\text { structures, JSCE }\end{array}$ & 2007 \\
\hline & \multirow[t]{2}{*}{ Periodicals } & Structural health monitoring Series & $\begin{array}{l}\text { Journal of The Socie- } \\
\text { ty of Naval Architects } \\
\text { of Japan (SNAJ) }\end{array}$ & 1992 \\
\hline & & $\begin{array}{l}\text { Special issue "technologies sup- } \\
\text { porting life lines and others }\end{array}$ & $\begin{array}{l}\text { Journal of JSNDI } \\
\text { (The Japanese Socie- } \\
\text { ty for Non-destructive } \\
\text { Inspection }\end{array}$ & 2006 \\
\hline \multirow[t]{6}{*}{ Oversea } & \multirow[t]{2}{*}{ Journal } & $\begin{array}{l}\text { Structural Control; Past, present, } \\
\text { and future }\end{array}$ & $\begin{array}{l}\text { Engineering Mechan- } \\
\text { ics, ASCE }\end{array}$ & 1997 \\
\hline & & $\begin{array}{l}\text { New sensors, Instrumentation and } \\
\text { Signal Interpretation }\end{array}$ & $\begin{array}{l}\text { Infrastructure } \\
\text { tems, ASCE }\end{array}$ & 2008 \\
\hline & \multirow[t]{4}{*}{$\begin{array}{l}\text { Conference } \\
\text { Proceeding }\end{array}$} & $\begin{array}{l}\text { Structural Control and Structural } \\
\text { health monitoring }\end{array}$ & IASCM & 2006 \\
\hline & & $\begin{array}{l}\text { Structural health monitoring and In- } \\
\text { telligent Infrastructure }\end{array}$ & ISHMII & 2007 \\
\hline & & $\begin{array}{l}\text { Application of Statistics and Prob- } \\
\text { ability in Civil Engineering }\end{array}$ & ICASP & 2007 \\
\hline & & Smart Structures and Materials & SPIE & 2006 \\
\hline
\end{tabular}




\subsection{Reference Survey}

\subsubsection{Summary of references}

Totally 136 references were reviewed and summarized by Tables 10 and 11 . Although a great number of figures and tables were contained. They are not shown in this paper because of the restriction of page numbers.

Table 10. Content of summary

\begin{tabular}{ll}
\hline Study items & \multicolumn{1}{c}{ Examples of study } \\
\hline Target structures & $\begin{array}{l}\text { Long-span bridges, viaducts, high-rise buildings, timber buildings, tun- } \\
\text { nels, dams, pipelines etc. }\end{array}$ \\
\hline Sensors & $\begin{array}{l}\text { Optical fibers, piezoelectric materials, AE sensors, accelerometer, wire- } \\
\text { less measurements, corrosion sensors, etc. }\end{array}$ \\
\hline Technologies & $\begin{array}{l}\text { System identifications, wave treatments, pattern recognitions, field tests, } \\
\text { assessment by NDT, etc }\end{array}$ \\
\hline $\begin{array}{l}\text { Possibility of im- } \\
\text { plementation }\end{array}$ & $\begin{array}{l}\text { System developments, performance test levels, proof test levels, imple- } \\
\text { mentation levels }\end{array}$ \\
\hline
\end{tabular}

Table 11. Number of summarized articles.

\begin{tabular}{llll}
\hline & $\begin{array}{l}\text { Technical } \\
\text { papers }\end{array}$ & $\begin{array}{l}\text { State-of-the- } \\
\text { arts and } \\
\text { commentary }\end{array}$ & Total \\
\hline Domestic & 50 & 5 & 55 \\
\hline Oversea & 86 & 0 & 86 \\
\hline Total & 136 & 5 & 141 \\
\hline
\end{tabular}

\subsubsection{Representation of matrix}

The result of the survey on sensing technologies and assessment methods is tabulated by Tables 12 and 13 . The results may be the most conveniently represented by a matrix method as shown in Figures 11 and 12.

Table 12. Sensing technologies and assessment methods.

\begin{tabular}{lll}
\hline \multicolumn{1}{c}{$\begin{array}{c}\text { Classifica- } \\
\text { tion }\end{array}$} & \multicolumn{1}{c}{ Target items } & \multicolumn{1}{c}{ Alternatives } \\
\hline Sensing & $\begin{array}{l}\text { Physical quanti- } \\
\text { ties for meas- } \\
\text { urement }\end{array}$ & $\begin{array}{l}\text { Deflections, strains, reactions, stresses, accelerations, } \\
\text { surface conditions, film thickness, cracks }\end{array}$ \\
\cline { 2 - 3 } & Target damages & $\begin{array}{l}\text { Corrosion, film deterioration, local deformation, stress- } \\
\text { es, fatigue, divergent oscillations, material deteriora- } \\
\text { tions }\end{array}$ \\
\cline { 2 - 3 } & Target levels & Member level, whole bridge system level \\
\cline { 2 - 3 } $\begin{array}{l}\text { Methods of } \\
\text { assessment }\end{array}$ & $\begin{array}{l}\text { Target perfor- } \\
\text { mances }\end{array}$ & \begin{tabular}{l} 
Serviceability, safety, durability \\
\cline { 2 - 3 }
\end{tabular} \\
\cline { 2 - 3 } & $\begin{array}{l}\text { Output } \\
\text { (targets) }\end{array}$ & $\begin{array}{l}\text { Accelerations, velocities, displacements, strains, exter- } \\
\text { nal loads, elastic waves, supersonic waves, acoustics }\end{array}$ \\
\hline & $\begin{array}{l}\text { (Whole system) Characteristic frequencies, vibration } \\
\text { modes, damping coefficients, } \\
\text { (Local parts) stiffness, damping factors } \\
\text { (Other) damage pattern, time of damage occurrence }\end{array}$ \\
\hline
\end{tabular}




\begin{tabular}{lll}
\hline $\begin{array}{l}\text { Applied struc- } \\
\text { tures }\end{array}$ & $\begin{array}{l}\text { Framed structures, buildings, long-span bridges, rail- } \\
\text { road tracks }\end{array}$ \\
\cline { 2 - 2 } & $\begin{array}{l}\text { Number of nec- } \\
\text { essary sensors }\end{array}$ \\
\hline
\end{tabular}

Table 13. Matrix Representation of Sensing Technologies

\begin{tabular}{|c|c|c|c|c|c|}
\hline $\begin{array}{l}\text { Measured phys- } \\
\text { ical quantities }\end{array}$ & $\begin{array}{l}\text { Target of as- } \\
\text { sessment }\end{array}$ & $\begin{array}{l}\text { Sensing } \\
\text { methods }\end{array}$ & Details & $\begin{array}{l}\text { Assessment } \\
\text { level }\end{array}$ & $\begin{array}{l}\text { Target per- } \\
\text { formance }\end{array}$ \\
\hline \multirow[t]{4}{*}{ Displacement } & \multirow[t]{2}{*}{$\begin{array}{l}\text { Local de- } \\
\text { formation }\end{array}$} & $\begin{array}{l}\text { Displacement } \\
\text { transducers }\end{array}$ & & $\begin{array}{l}\text { Whole system } \\
\text { level }\end{array}$ & Serviceability \\
\hline & & $\begin{array}{l}\text { Peak dis- } \\
\text { placement } \\
\text { memory sen- } \\
\text { sor }\end{array}$ & & Member level & Safety \\
\hline & \multirow[t]{2}{*}{ Vibration } & $\begin{array}{l}\text { Digital cam- } \\
\text { era }\end{array}$ & & Member level & $\begin{array}{l}\text { Safety \& ser- } \\
\text { viceability }\end{array}$ \\
\hline & & $\begin{array}{l}\text { Laser dop- } \\
\text { pler vibrator }\end{array}$ & & $\begin{array}{l}\text { Whole system } \\
\text { level }\end{array}$ & $\begin{array}{l}\text { Safety \& } \\
\text { durability }\end{array}$ \\
\hline \multirow[t]{7}{*}{ Strains } & \multirow[t]{6}{*}{$\begin{array}{l}\text { Local de- } \\
\text { formation }\end{array}$} & Optical fiber & FBG & Member level & $\begin{array}{l}\text { Safety \& ser- } \\
\text { viceability }\end{array}$ \\
\hline & & & BOTDR & Member level & safety \\
\hline & & & OTDR & Member level & $\begin{array}{l}\text { Safety \& ser- } \\
\text { viceability }\end{array}$ \\
\hline & & & SOFO & Member level & Serviceability \\
\hline & & $\begin{array}{l}\text { Peak strain } \\
\text { memory } \\
\text { sensor }\end{array}$ & & Member level & $\begin{array}{l}\text { Durability \& } \\
\text { safety }\end{array}$ \\
\hline & & $\begin{array}{l}\text { Magnetic } \\
\text { strain sensor }\end{array}$ & & Member level & Safety \\
\hline & Fatigue & $\begin{array}{l}\text { Piezoelectric } \\
\text { material }\end{array}$ & $\begin{array}{l}\text { Piezoelectric } \\
\text { film }\end{array}$ & Member level & Serviceability \\
\hline \multirow[t]{2}{*}{ Stresses } & $\begin{array}{l}\text { Local } \\
\text { deformation }\end{array}$ & EM sensor & & Member level & Safety \\
\hline & Local stress & Slot stress & & $\begin{array}{l}\text { Whole system } \\
\text { level }\end{array}$ & $\begin{array}{l}\text { Safety \& du- } \\
\text { rability }\end{array}$ \\
\hline \multirow[t]{8}{*}{ Accelerations } & \multirow{4}{*}{$\begin{array}{l}\text { Local de- } \\
\text { formation }\end{array}$} & Optical fibers & BOCDA & Member level & Safety \\
\hline & & $\begin{array}{l}\text { Piezoelectric } \\
\text { material }\end{array}$ & $\begin{array}{l}\text { Piezoelectric } \\
\text { elements }\end{array}$ & Member level & $\begin{array}{l}\text { Safety \& ser- } \\
\text { viceability }\end{array}$ \\
\hline & & \multirow{2}{*}{$\begin{array}{l}\text { Acceleration } \\
\text { sensor }\end{array}$} & & Member level & Durability \\
\hline & & & MICA Mote & $\begin{array}{l}\text { Whole system } \\
\text { level }\end{array}$ & Serviceability \\
\hline & Vibration & Optical fibers & FBG & Member level & Safety \\
\hline & \multirow[t]{3}{*}{$\begin{array}{l}\text { Decrement } \\
\text { of rigidity }\end{array}$} & $\begin{array}{l}\text { Piezoelectric } \\
\text { material }\end{array}$ & $\begin{array}{l}\text { Piezoelectric } \\
\text { elements }\end{array}$ & Member level & $\begin{array}{l}\text { Safety \& ser- } \\
\text { viceability }\end{array}$ \\
\hline & & $\begin{array}{l}\text { Oscillation } \\
\text { Gyro sensor }\end{array}$ & & Member level & $\begin{array}{l}\text { Safety \& ser- } \\
\text { viceability }\end{array}$ \\
\hline & & AE sensors & $\begin{array}{l}\text { Smart AE } \\
\text { sensors }\end{array}$ & $\begin{array}{l}\text { Whole system } \\
\text { level }\end{array}$ & $\begin{array}{l}\text { Safety \& du- } \\
\text { rability }\end{array}$ \\
\hline \multirow[t]{5}{*}{ Surface state } & \multirow[t]{4}{*}{ Corrosion } & $\begin{array}{l}\text { Piezoelectric } \\
\text { material }\end{array}$ & $\begin{array}{l}\text { Macro-fiber } \\
\text { composite }\end{array}$ & Member level & $\begin{array}{l}\text { Safety \& du- } \\
\text { rability }\end{array}$ \\
\hline & & $\begin{array}{l}\text { Impedance } \\
\text { measurement } \\
\text { chips }\end{array}$ & & Member level & $\begin{array}{l}\text { Safety \& du- } \\
\text { rability }\end{array}$ \\
\hline & & $\begin{array}{l}\text { Corrosion } \\
\text { environment } \\
\text { sensors }\end{array}$ & & Member level & $\begin{array}{l}\text { Serviceability } \\
\& \text { durability }\end{array}$ \\
\hline & & $\begin{array}{l}\text { Corrosion } \\
\text { sensors }\end{array}$ & & $\begin{array}{l}\text { Whole system } \\
\text { level }\end{array}$ & $\begin{array}{l}\text { Safety \& ser- } \\
\text { viceability }\end{array}$ \\
\hline & $\begin{array}{l}\text { Deterioration } \\
\text { of paint } \\
\text { film }\end{array}$ & $\begin{array}{l}\text { Digital } \\
\text { camera }\end{array}$ & & Member level & Safety \\
\hline
\end{tabular}




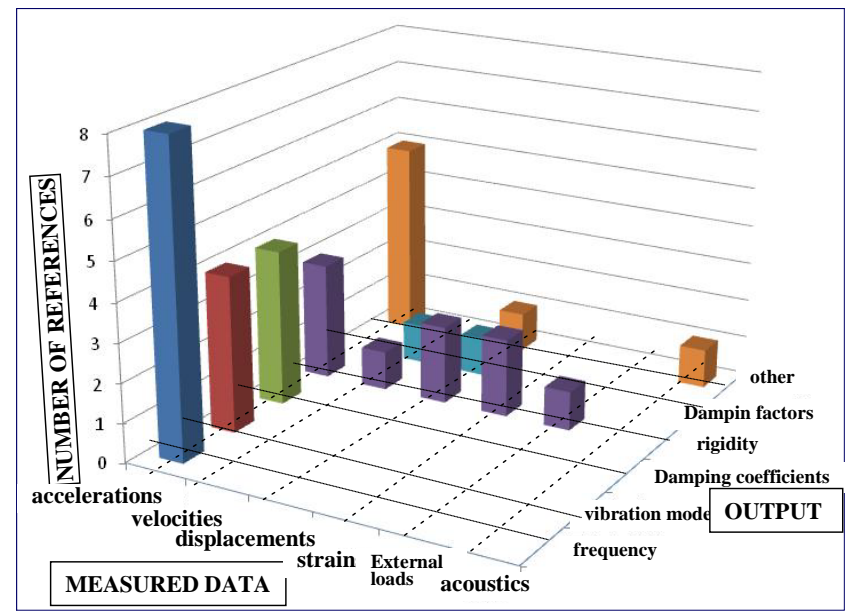

Figure 11. Number of references with respect to measured physical quantities and output.

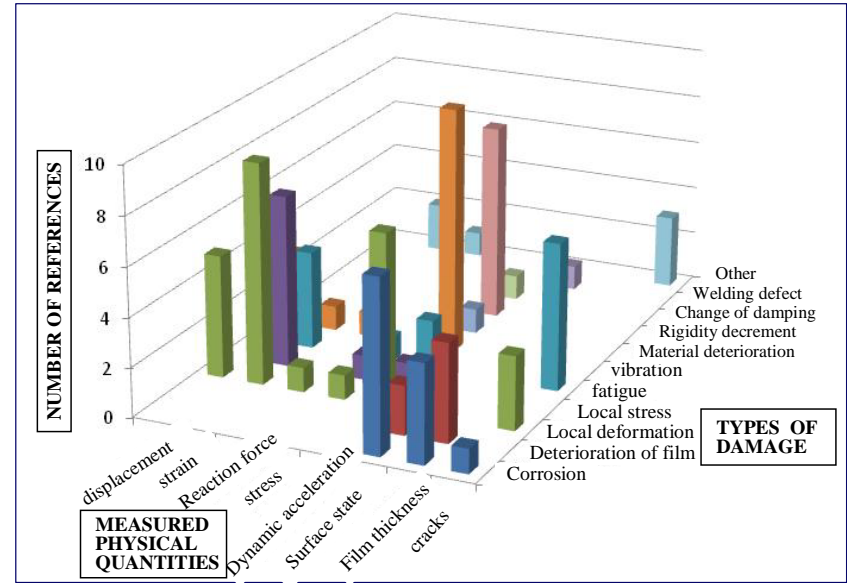

Figure 12. Number of references in the matrix form with respect to measured physical quantities and types of damage.

\subsubsection{Sensing technology}

The following observations may be made:

(1) Status of developments of sensing technologies

a. Majority of measured physical quantities are strains and accelerations. However, the number of instances of stresses, reaction forces, ph and temperature is quite few.

b. Local deformations and vibrations constitute the majority of the diagnosed damages. The number of instances of direct measurements is quite few for material deterioration and decrement of rigidity target damage.

\subsubsection{Examples of advanced technology}

Examples of advanced application to measuring diverse physical quantities are cited. Only development of measuring methods other than for strain and acceleration measurements and for real structures 
(1) Application of optical fibers to $\mathrm{pH}$ and $\mathrm{AE}$ measurements to reinforced concrete structures (EBG method) (Habel 2007) See Figure 13.

(2) Stress measurement of prestress tendons by detachable sensors for measuring electromagnetic permeability (Sumitro 2007). See Figure 14.

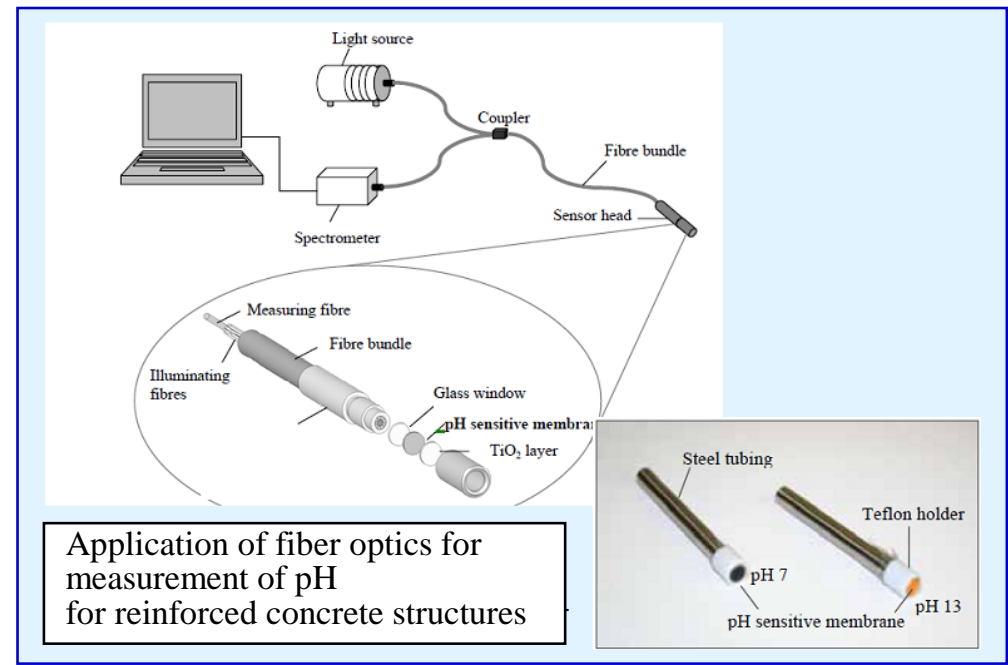

Figure 13. Application of optical fibers to $\mathrm{pH}$ and $\mathrm{AE}$ measurements to reinforced concrete structures (EBG method) (Habel 2007)

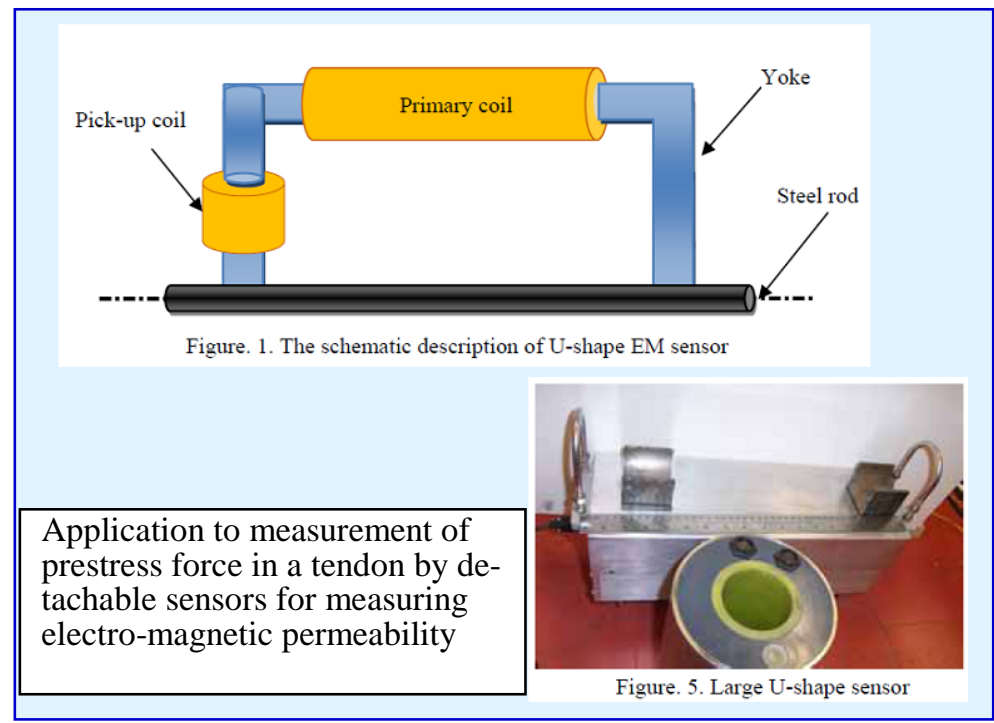

Figure 14. Stress measurement of prestress force in a tendon by detachable sensors for measuring electro-magnetic permeability (Sumitro 2007). 


\section{CONCLUDING REMARKS}

This paper is an English version of JSSC report on the Longevity and Structural health monitoring Technologies of Bridges but limited to only some selected parts of the whole study. The main body of the paper is the summary of the state-of-the-art of the present technologies and the results of discussions among committee members of Longevity and Structural health monitoring Technologies of Bridges of JSSC. It is the authors' great joy if this could serve as a reference of the technologies of longevity and structural health monitoring for steel bridges.

\section{ACKNOWLEDGMENT}

The authors would like to deeply acknowledge the financial support by JSSC, the Society of Steel Construction of Japan and greatly appreciate many valuable suggestions and encouragements by the committee members of Longevity and Structural health monitoring Technologies of Bridges of JSSC. The authors take this opportunity to express their sincere appreciation for almost unanimous attendance and enthusiastic discussions of the committee members each time of the meetings.

\section{REFERENCES}

Abe, M. 2008. Activity of bridge maintenance toward the age of longevity of bridges. Report of Seminar. EXTEC, 84, 61-62 (in Japanese).

BMSG. 2004. Guide to management for road bridges. Bridge Management Study Group, Japan Bridge Engineering Center, JBEC (in Japanese).

Habel, W.R. et.al. 2007. Fiber Optic Sensors For Long-Term SHM in Civil Engineering Applications, Proc International Conference on Structural Health Monitoring of Intelligent Infrastructure.

Ishida, Sato, Fujikawa, Sekiguchi and Hashimoto. 2006. Concept of corrosion protection of steel for D-runway -For reduction of LCC-. $2^{\text {nd }}$ Seminar on report of construction of Drunway of Tokyo International Airport (Haneda). 8.1-8.8 (in Japanese).

JAPH, 1999. Technological Standard and Commentary of Port and Harbor Facilities, Japanese Association of Port and Harbor, 1 \& 2, (in Japanese).

JSSC 1991. Study on lifetime of steel structures. Report of Task Committee on Lifetime of Steel Structures, 29-30 (in Japanese).

JTS. Titanium World -In pursuit of its unlimited potentialities and realization of dreams-, 2000. The Japan Titanium Society, http://www.titan-japan.com, 7, (in Japanese).

Kaneko, Mizoue and Naito.1999. Corrosion protection inside a box girder by dry air intake New Onomichi Bridge-, Bridge and Foundation, 33(5), 31-34 (in Japanese).

Kato, M.1983. Recent topics in maintenance. Journal of JSCE. 68(11): 2-5 (in Japanese).

Kitagawa, Furuya, Nakamura and Suzumura. 2001. Study on corrosion protection performance by dry air intake system for main cables for suspension bridge cables. Proc. JSCE 672(VI50), 145-154 (in Japanese).

MLIT 2002. White paper of the Government of Japan. MLIT, Ministry of Land, Infrastructure and Transport and Tourism (http://www.mlit.go.jp/hakusyo/mlit/h14/H14/index.html) (in Japanese)

MLIT 2008. Suggestions for preventive maintenance of roadway bridges. Report of Meeting by experts toward Preventive Maintenance of Roadway Bridges, MLIT, Ministry of Land, Infrastructure and Transport and Tourism (in Japanese).

NILIM 2004. Study on estimation of the lifetime of road bridges, National Institute for Land and Infrastructure Management, NILIM Report, 223 (in Japanese).

Nippon Steel 2000. Titanium Clad, Cat. No. TC026, (in Japanese).

PWRI Bridge Laboratory. 1997. Study on replacement of bridges (III), PWRI Report 3512 (in Japanese).

Sumitro, S. et.al.2007. Removable Actual-Stress Sensor, Proc International Conference on Structural Health Monitoring of Intelligent Infrastructure. 